\title{
Blood transfusions and human recombinant erythropoietin in premature newborn infants
}

\author{
Paula Williamson, Gill Griffiths, Derek Norfolk, Malcolm Levene
}

Transfusion with concentrated erythrocytes is a common form of treatment in many very premature infants. It is estimated that over $80 \%$ of infants requiring intensive care have received at least one blood transfusion as part of their treatment, and $37 \%$ more than two. ${ }^{1}$ Frequent blood transfusions expose the infants to multiple donors. One survey reported that infants who were given more than one transfusion received blood from a mean of 4.9 donors. ${ }^{2}$ There is increasing anxiety concerning the potential adverse effects of blood transfusions and various methods for reducing the need for blood transfusions in sick premature infants have been investigated. In particular, the role of human recombinant erythropoietin has been the subject of a number of controlled studies: we describe an overview of the efficacy of this form of treatment.

\section{Potential hazards of blood transfusion}

TRANSFUSION TRANSMITTED INFECTION

The acquisition of transfusion related viral infection is a particular anxiety in premature infants, because of their immunological immaturity and the potential for the full clinical expression of diseases such as hepatitis $C$ or HIV infection later in life. Provision of a "safe" blood supply is largely based on donor screening and self-referral. Blood donors in the United Kingdom are routinely screened for syphilis, hepatitis B surface antigen (HBsAg), antibodies to HIV-1 and -2 and, since 1991, antibodies to hepatitis $\mathrm{C}$ virus (HCV). The recent controversy over the introduction of routine HCV screening forcibly reminds us that unrecognised infectious agents may be present in the blood supply before effective screening tests are available. Donors with recently acquired viral infection may also occasionally give blood in the "window period" before developing screen detectable antibodies. Blood for premature infants is also screened for antibodies to cytomegalovirus (CMV). CMV antibody screening reduces the risk of transmission to less than $4 \%,{ }^{3}$ but a small proportion of CMV seronegative donors have mononuclear cells which are positive for CMV DNA by the polymerase chain reaction. ${ }^{4}$ Similar arguments may apply to other leucocyte associated viruses, such as HTLV I and II (not routinely screened for in the United Kingdom because of their low prevalence in the donor population).
RESIDUAL DONOR LEUCOCYTES

Cellular blood components produced by standard techniques contain clinically important numbers of residual donor leucocytes (2-3 x 10 per red cell unit). These "contaminating" leucocytes have been implicated in a range of immunological and infective complications of blood transfusion. ${ }^{5}$ Recent data also suggest that leucocytes may generate inflammatory cytokines during storage and cause febrile transfusion reactions. ${ }^{6}$ However, HLA-alloimmunisation and non-haemolytic febrile transfusion reactions are a minimal clinical problem in newborn infants, presumably because of their immunological immaturity. Transfusion related graft versus host disease contracted from donor lymphocytes is also rare except in infants with severe congenital defects of cellular immunity. ${ }^{7}$ Perhaps of most concern is the potentially "immunosuppressive" effect of transfused leucocytes. ${ }^{8}$ Documented changes include reductions in natural killer cell activity and CD4 lymphocytes, an increase in CD8 (suppressor) $T$ cells and B lymphocytes, and impaired secretion of cytokines such as II-2. ${ }^{9}$ These changes have been implicated in the improved survival of patients with renal allografts and in increased rates of cancer recurrence and bacterial infection after surgery. ${ }^{5}$ The use of leucocyte depleted or autologous blood products may prevent these complications. ${ }^{5}$ Blood transfusion with unscreened donor plasma increases mortality in infants with necrotising enterocolitis who have the Thomson-Friedenreich cryptantigen (TCA) exposed on their red cells. ${ }^{10}$

FREE RADICAL GENERATION

Free radicals damage biological membranes by inducing lipid peroxidation. This has been suggested as the mechanism for bronchopulmonary dysplasia, retinopathy of prematurity, and intraventricular haemorrhage in premature infants. ${ }^{11}$ Ferrous iron fuels the production of free radicals and the premature infant has a very limited capacity to assimilate exogenous iron. ${ }^{12}$ Blood transfusion increases iron load of the neonate and this may be an important factor in the development or exacerbation of these complications.

\section{Strategies to reduce the need for transfusion}

IATROGENIC BLOOD LOSS

Sick premature babies lose a considerable amount of blood as the result of the need for repeated investigations. One recent study 
Table 1 Summary of designs of randomised controlled trials of recombinant human erythropoietin in premature infants

\begin{tabular}{|c|c|c|c|c|c|c|c|}
\hline Study (year of publication) & $\begin{array}{l}\text { Dose } \\
\text { (U/kg/ } \\
\text { week) }\end{array}$ & $\begin{array}{l}\text { Route of } \\
\text { administration }\end{array}$ & Duration of treatment & Iron & $\begin{array}{l}\text { Gestational } \\
\text { age for entry } \\
\text { (weeks) }\end{array}$ & $\begin{array}{l}\text { Time of } \\
\text { randomisation } \\
\text { (days of life) }\end{array}$ & $\begin{array}{l}\text { Duration of } \\
\text { follow up }\end{array}$ \\
\hline $\begin{array}{l}\text { Obladen et al }(1991)^{25} \\
\text { Shannon et al }(1991)^{20}\end{array}$ & $\begin{array}{r}70 \\
200\end{array}$ & $\begin{array}{l}\text { Subcutaneous } \\
\text { Intravenous }\end{array}$ & $\begin{array}{l}\text { Until day } 25 \text { of life } \\
6 \text { weeks }\end{array}$ & $\begin{array}{l}2 \mathrm{mg} / \text { day from day } 14 \text { of life } \\
3 \mathrm{mg} / \text { day }\end{array}$ & $\begin{array}{l}28-32 \\
\leqslant 33\end{array}$ & $\begin{array}{l}\text { Day } 4 \\
\text { Days } 10-35\end{array}$ & $\begin{array}{l}\text { Day } 25 \text { of life } \\
30 \text { weeks after } \\
\text { randomisation }\end{array}$ \\
\hline Shannon et al $(1992)^{21}$ & $500^{\star \star}$ & Subcutaneous & 6 weeks & $3 \mathrm{mg} / \mathrm{kg} /$ day & $\leqslant 33$ & Days 4-28 & $\begin{array}{l}6 \text { weeks after } \\
\text { randomisation }\end{array}$ \\
\hline $\begin{array}{l}\text { Bechensteen et al } \\
\quad(1993)^{22}\end{array}$ & 300 & Subcutaneous & Until 7 weeks of age & $18 \mathrm{mg} /$ day from day 21 of life & $\begin{array}{l}(\mathrm{BW}= \\
900-1400 \mathrm{~g})\end{array}$ & Day 21 & 16 weeks of age \\
\hline Emmerson et al $(1993)^{16}$ & $100-300$ & Subcutaneous & Until discharge home & $6.25 \mathrm{mg}$ from 4 weeks of age & $27-33$ & After day 7 & $\begin{array}{l}3 \text { months after } \\
\text { discharge }\end{array}$ \\
\hline Ohls et al (1993) ${ }^{18}$ & 1400 & Intravenous & 14 days & $2 \mathrm{mg} / \mathrm{kg} /$ day $^{\star}$ & N/A & Day 1 & Day 20 of life \\
\hline Ohls et al (1993) 19 & 1400 & Subcutaneous & 10 days & $3-5 \mathrm{mg} / \mathrm{kg} /$ day & N/A & $\begin{array}{l}\text { Before day } \\
70\end{array}$ & $\begin{array}{l}15 \text { days after } \\
\text { randomisation }\end{array}$ \\
\hline Soubasi et al $(1993)^{26}$ & 300 & Subcutaneous & Until 6 weeks of age & $\begin{array}{l}3 \mathrm{mg} / \mathrm{kg} / \text { day from day } 15 \\
\text { of life }\end{array}$ & 31 & Days 1-7 & 6 months of age \\
\hline $\begin{array}{l}\text { Maier et al }(1994)^{24} \\
\text { Meyer et al }(1994)^{17}\end{array}$ & $\begin{array}{l}750 \\
600 t t\end{array}$ & $\begin{array}{l}\text { Subcutaneous } \\
\text { Subcutaneous }\end{array}$ & $\begin{array}{l}\text { Until } 4250 \mathrm{U} / \mathrm{kg} \text { received } \\
6 \text { weeks }\end{array}$ & $\begin{array}{l}2 \mathrm{mg} / \text { day from day } 14 \\
2-3 \mathrm{mg} / \mathrm{kg} / \text { dayt }\end{array}$ & $\begin{array}{l}\leqslant 34 \\
28-32\end{array}$ & $\begin{array}{l}\text { Day } 3 \\
\text { Days } 14-56\end{array}$ & $\begin{array}{l}\text { Day } 42 \text { of life } \\
6 \text { weeks after } \\
\text { randomisation }\end{array}$ \\
\hline Shannon et al (1995) ${ }^{13}$ & 500 & Subcutaneous & 6 weeks/discharge home & $3 \mathrm{mg} / \mathrm{kg} /$ day from entry $\ddagger$ & $<31$ & Days 7-42 & 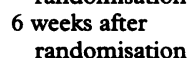 \\
\hline Ishikawa $^{23}$ & 400 & Subcutaneous & 8 weeks & $\begin{array}{l}4 \mathrm{mg} / \mathrm{kg} / \text { day if serum iron } \\
\text { below } 60 \mathrm{ug} / \mathrm{dl}\end{array}$ & $\begin{array}{l}(\mathrm{BW}: 500- \\
2000 \mathrm{~g})\end{array}$ & Days $10-40$ & $\begin{array}{l}11 \text { weeks after } \\
\text { randomisation }\end{array}$ \\
\hline
\end{tabular}

ᄎ When on $70 \mathrm{ml} / \mathrm{kg} /$ day enterally, increasing to 6 when $>100 \mathrm{ml} / \mathrm{kg} /$ day.

$\star \star$ doubled to 1000 after $2-3$ weeks if reticulyte count target not reached.

$\dagger$ Increased on basis of hypochromic cells.

tt Increase of 150 if $6 \%$ haematocrit reduction.

$\ddagger$ Increasing to 6 when full feeding commenced.

found that during the first three weeks of life, moderately ill infants weighing $\leqslant 1250 \mathrm{~g}$ lose almost $50 \mathrm{ml}$ of blood as the result of sampling. ${ }^{13}$ This represents more than half the circulating blood volume of these infants and is equivalent to a blood loss of 3.51 in an adult Another study has shown that $26 \%$ of very low birthweight (VLBW) infants had a cumulative blood loss which exceeded their red blood cell mass at birth. ${ }^{14}$ It may be possible to reduce this volume of blood loss by reviewing blood sampling regimens and using smaller volumes of blood in microassays.

TRANSFUSION NEEDS

Tissue oxygen delivery depends on respiratory function, tissue perfusion, the haemoglobin concentration and the oxygen dissociation curve of the haemoglobin. There is no scientific basis for currently used transfusion protocols and these vary significantly from neonatal unit to unit. Shannon et al have developed conservative transfusion criteria for growing preterm infants in additional oxygen and this has been shown to markedly reduce the number of blood transfusions compared with a traditional less strict policy and with apparently no detrimental effect on the babies. $^{15}$

\section{Recombinant human erythropoietin (r-HuEPO)}

It has been suggested that non-iatrogenic anaemia of prematurity is due to low circulating erythropoietin concentrations. In recent years bone marrow stimulation with r-HuEPO has been shown to have some benefit in reducing transfusion needs, ${ }^{13}{ }^{16-26}$ but there has also been concern about the safety of r-HuEPO because of a suggested increase in the risk of cot death in one trial, at an unplanned interim analysis. ${ }^{16} \mathrm{We}$ undertook a systematic overview of randomised trials of r-HuEPO (both published and unpublished) in premature infants to collate informa- tion on the effects on mortality and the need for blood transfusions, the results of which are published below.

\section{Overview of r-HuEPO studies}

We included all randomised trials of $\mathrm{r}-\mathrm{HuEPO}$ injections compared with either placebo, ${ }^{13}{ }^{16-21}$ or no injections ${ }^{22-26}$ in premature neonates. This included pilot safety studies and a dose ranging study ${ }^{16}$ which were randomised and controlled. Trials fulfilling the above criteria, known to have been discontinued at an interim analysis stage, were also eligible for inclusion. Trials were excluded if r-HuEPO and iron were compared with no injections and no iron, if $\mathrm{r}-\mathrm{HuEPO}$ was compared with erythrocyte transfusions, and where the trial was nonrandomised and/or uncontrolled.

Trials were located through a search of the published findings including abstracts, the Cochrane Collaboration trial register, conference proceedings, and through direct contact with researchers and pharmaceutical companies manufacturing $r$-HuEPO. The information from 12 completed randomised trials fulfilling the above criteria was ascertained (table 1). Details from one eligible trial ${ }^{27}$ were not available at the time of writing. Two unpublished trials were identified, ${ }^{23}{ }^{27}$ but a further study, mentioned to us by one researcher, has not been verified.

The average gestational age was below 28 weeks in only four studies. ${ }^{13}{ }^{19-21}$ Eligibility criteria based on respiratory support varied widely. Studies evaluated both prophylactic (treatment started before the third week of life) and therapeutic (started after the third week of life) use of $r$-HuEPO. There was a very wide variation in the weekly $r-H u E P O$ dose (70$1400 \mathrm{U} / \mathrm{kg}$ ) and the length of treatment varied from 10 days to eight weeks on discharge home from hospital. There was variation in iron and vitamin $\mathrm{E}$ supplementation but, by design this overview included only trials with no planned 
Table 2 Summary of data for transfusion and mortality endpoints in randomised controlled trials of $r$-HuEPO in premature infants

\begin{tabular}{|c|c|c|c|c|c|}
\hline \multirow[b]{2}{*}{ Study (year of publication) } & \multicolumn{2}{|l|}{ Transfusion } & \multicolumn{2}{|l|}{ Mortality } & \multirow[b]{2}{*}{ SIDS } \\
\hline & $\begin{array}{l}r-\mathrm{HuEPO} \\
(\mathrm{No} / \%)\end{array}$ & $\begin{array}{l}\text { Control } \\
\text { (No/\%) }\end{array}$ & $r-H u E P O$ & Control & \\
\hline Obladen et al $(1991)^{25}$ & $23 / 38(61)$ & $29 / 45(64)$ & $0 / 43$ & $2 / 50$ & No cases \\
\hline Shannon et al $(1991)^{20}$ & $6 / 10(60)$ & $8 / 10(80)$ & $1 / 10$ & $0 / 10$ & No cases \\
\hline Shannon et al $(1992)^{21}$ & $1 / 40(25)$ & $3 / 40(75)$ & $0 / 40$ & $0 / 40$ & No cases \\
\hline Bechensteen et al (1993) & $0 / 14(0)$ & $4 / 15(27)$ & $0 / 14$ & $0 / 15$ & No cases \\
\hline Emmerson et al $(1993)^{16}$ & $7 / 15(47)$ & $7 / 80(88)$ & $3 / 15$ & $0 / 80$ & $\begin{array}{l}2 \text { cases } 4 \text { weeks after discharge in } \\
\text { r-HuEPO group }\end{array}$ \\
\hline Ohls et al (1993) ${ }^{18}$ & $2 / 10(20)$ & $7 / 10(70)$ & $0 / 10$ & $0 / 10$ & No cases \\
\hline Ohls et al (1993) ${ }^{19}$ & $1 / 10(10)$ & $4 / 50(80)$ & $0 / 10$ & $0 / 50$ & No cases \\
\hline Soubasi et al (1993) ${ }^{26}$ & $19 / 25(76)$ & $18 / 19(95)$ & $2 / 25$ & $1 / 19$ & No cases \\
\hline Maier et al $(1994)^{24}$ & $60 / 120(50)$ & $81 / 121(67)$ & $3 / 120$ & $3 / 121$ & $\begin{array}{l}2 \text { cases in r-HuEPO group, } \\
1 \text { case in control group }\end{array}$ \\
\hline Meyer et al (1994) ${ }^{17}$ & $6 / 40(15)$ & $17 / 40(43)$ & $2 / 40^{\star}$ & $2 / 40$ & $\begin{array}{l}1 \text { case at age } 4 \text { months in } \\
\text { r-HuEPO group }\end{array}$ \\
\hline $\begin{array}{l}\text { Shannon et al }(1995)^{13} \\
\text { Ishikawa }^{23}\end{array}$ & $\begin{array}{c}44 / 77(57) \\
2 / 32(6)\end{array}$ & $\begin{array}{l}55 / 80(69) \\
12 / 30(40)\end{array}$ & $\begin{array}{l}0 / 77(1 / 77) \\
0 / 32\end{array}$ & $\begin{array}{l}1 / 80(4 / 80) \dagger \\
0 / 30\end{array}$ & $\begin{array}{l}2 \text { probable cases in control group } \\
\text { No cases }\end{array}$ \\
\hline
\end{tabular}

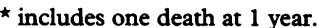

† where data on 125 infants with six month follow up in clinics included.

differential supplementation. Such clinical heterogeneity indicated by the wide range of transfusion episodes in the control groups (table 2) makes a single effect estimate from a quantitative meta-analysis difficult to interpret.

Trial quality varied considerably. Of the 12 completed trials, eight were reported to be blind and there were no reports of this having been broken. ${ }^{13}{ }^{16-2124}$ The method of randomisation was poorly described in most studies. The imbalance in numbers assigned to each group in one trial with planned randomisation ${ }^{26}$ was due to chance (Soubasi V, personal communication).

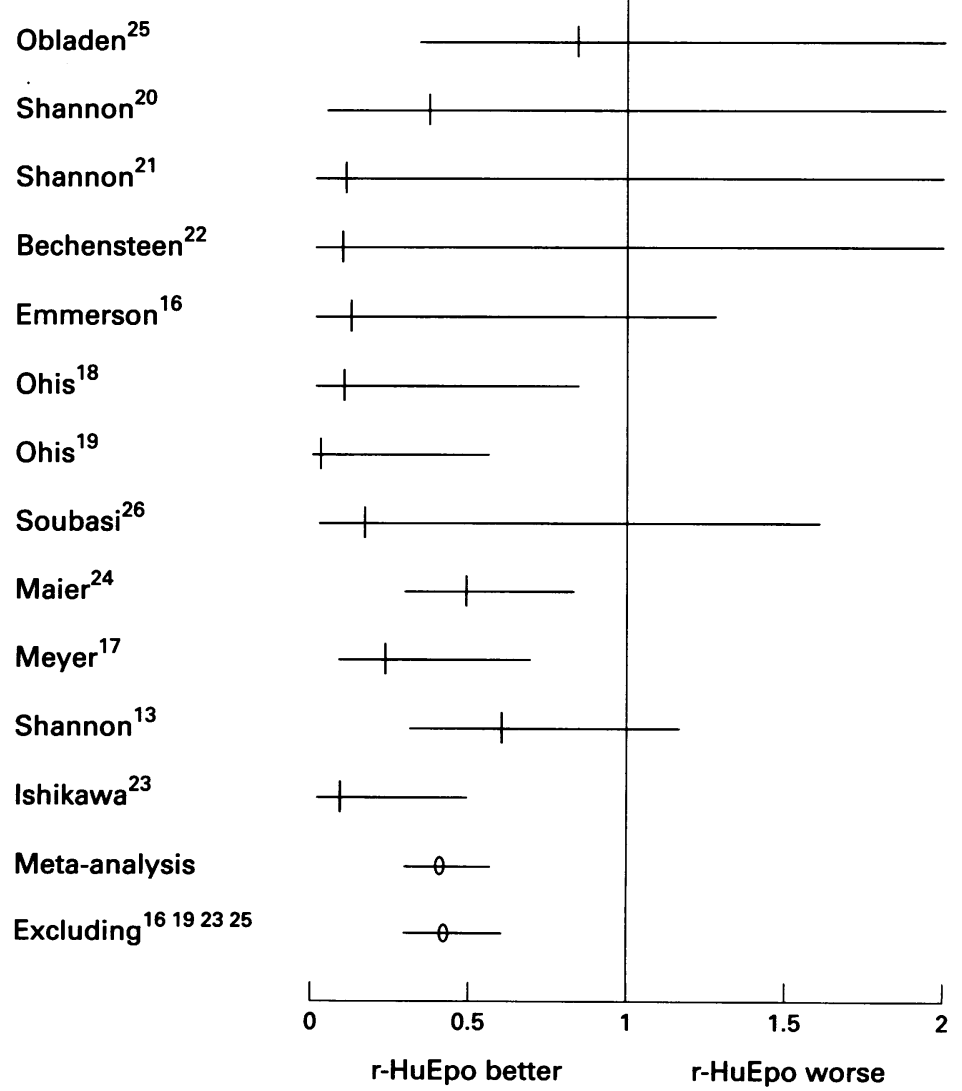

Trial

Randomised infants were excluded from the analysis in three studies. ${ }^{16} 2325$ Strict transfusion criteria were not applied in several. ${ }^{1922} 26$

Publication bias may affect the overview, and setting a minimum number of infants/events for trial inclusion may reduce this bias. As the main aim was to collate information on safety, results from all eligible trials are presented (table 2). However, publication bias may affect the overview of efficacy, although less weight is given to smaller trials in the meta-analysis.

There was no obvious trend towards increased total mortality in infants treated with $\mathrm{r}$-HuEPO from these studies. Longer term follow up, however, went beyond the sixth month of life in only three studies. No increase in the incidence of neutropenia has been reported. There are conflicting results with respect to septicaemia in three studies. ${ }^{13} 1724$

The studies consistently report that r-HuEPO treatment is associated with some reduction in the proportion of infants transfused (fig 1). Taken as a whole, there is strong evidence to suggest that rHuEPO reduces the need for blood transfusion (Cochran-MantelHaentzel $\chi^{2}$ statistic $=35.2,1 \mathrm{df} ; \mathrm{P}<0.0001$ ).

This conclusion is unchanged after the exclusion of trials terminated early ${ }^{16}$ or not analysed by intention to treat. ${ }^{192325}$ The evidence against homogeneity of treatment effects in the trials is minimal $\left(\chi^{2}\right.$ statistic $=17.3,11 \mathrm{df}$; $\mathrm{P}=0.099$ ). Indeed, after exclusion of the trials terminated early or not analysed by intention to treat, which may show exaggerated effect sizes, there is no evidence of a lack of homogeneity $\left(\chi^{2}\right.$ statistic $\left.=6.8,7 \mathrm{df} ; \mathrm{P}>0.1\right)$. One of the excluded studies ${ }^{25}$ was a pilot using only a low weekly dose of r-HuEPO. The conclusions from this overview must be viewed in terms of the fact that all the studies recruited small numbers of infants; only two studies enrolled more than 100 subjects.

\section{Conclusions}

Clearly, there is no single strategy which can reduce the exposure of premature infants to blood transfusions. It has been estimated that $90 \%$ of all erythrocyte transfusions in neonates are for replacement of iatrogenic losses. ${ }^{28}$
Figure 1 Odds ratio of the need for at least one transfusion (95\% confidence interval) in 12 trials of $r$-HuEPO. Odds ratio less than unity represent beneficial effects. Trial size is effects model. the total number of patients with transfusion data given; meta-analysis assumes a fixed 
Strategies directed at critically reviewing the need for all the blood samples taken in the neonatal nursery, and further developments of micromethods, may reduce this degree of unacceptable blood loss.

A simple policy of satellite packs of blood, allowing up to eight transfusions from a single donor ${ }^{2}$ and extending the expiry date of unused blood to 35 days, has significantly reduced the exposure of babies to multiple donors. ${ }^{28}$

Our overview has shown that r-HuEPO seems to have a potential role in reducing the need for blood transfusions as the result of anaemia of prematurity. All studies reported some degree of reduction in the proportion of infants transfused after $\mathrm{r}-\mathrm{HuEPO}$ treatment.

The results of this overview do not suggest any adverse effect of r-HuEPO on either early mortality or neutropenia. These trials, however, involve small numbers of infants and rarely followed them beyond six months of life. A number of important questions remain unresolved with respect to r-HuEPO. It is the most immature infants who are most likely to develop anaemia of prematurity and the dose response relation of $\mathrm{r}-\mathrm{HuEPO}$ in these most immature babies is not known. The requirements for iron, folate, and other supplements required by babies receiving $\mathrm{r}-\mathrm{HuEPO}$ have not been well studied. Further large multicentre trials with longer term follow up, which address health economic issues, need to be undertaken before recommendations about the routine use of $r-H u E P O$ can be made.

An approach to avoiding blood transfusion using r-HuEPO alone is of limited benefit, because of the massive iatrogenic blood losses incurred in the first few weeks of life before $\mathrm{r}-\mathrm{HuEPO}$ is likely to have a significant effect. Shannon ${ }^{13}$ recommends the routine administration of $r-H u E P O$ in preterm infants, but this study also reported that the infants in their study had received an average of 3.5 transfusions before enrolment. Shannon showed that the r-HuEPO group required a mean (SD) of 1.1 (1.5) transfusions compared with 1.6 (1.7) in the control group. ${ }^{13}$ This modest reduction in the number of red cell transfusions may, however, not be clinically useful. Volume of blood given may be more important and in their study a mean (SD) of 16.5 (23) $\mathrm{ml}$ of packed red cells was transfused in the r-HuEPO group compared with 23.9 (25.7) $\mathrm{ml}$ in the control group.

Further research is required to evaluate the effects of restrictive transfusion regimens in premature infants. This may be the most cost effective way of reducing exposure to multiple blood transfusions.

1 Brown MS, Berman ER, Luckey D. Prediction of the need for transfusion during anaemia of prematurity. 7 Pediat 1990;116:773-8.
2 Wood A, Wilson N, Skacel P, Thomas R, Tidmarsh E, Yale $C$, et al. Reducing donor exposure in preterm infants requiring multiple blood transfusions. Arch Dis Child 1995;72:F29-F33.

3 Yeager AS, Grumet FC, Hafleigh EB, Arvin AM, Bradley JS Prober CG. Prevention of transfusion-acquired cytomega-
lovirus infections in newborn infants. $\mathcal{f}$ Pediatr 1981; 98:281-3.

4 Stanier P, Taylor DL, Kitchen AD, Wales N, Tryhorn Y, Tyms AS. Persistence of cytomegalovirus in periphera blood from blood donors. BMF 1989;299:897-8.

5 Norfolk DR, Williamson LM. Leucodepletion of blood products by filtration. Blood Reviews 1995;9:7-14.

6 Heddle NM, Klama L, Singer J, Richards C, Fedak P, Walker I, et al. The role of plasma from platelet calker 1 , et al. The role of plasma from platelet 331:625-8.

7 Andersen KC, Weinstein JH. Transfusion-associated graftversus-host disease. $N$ Engl f Med 1990;323:315-21.

8 Perkins HA. Transfusion-induced immunologic unresponsiveness. Transfus Med Rev 1988;2:196-203.

9 Blumberg N, Heal JM. Immunology of blood transfusion. Curr Opin Hematol 1993; 330-6.

10 Novak RW, Abbott AK, Klein RL. T-cryptantigen determination affects mortality in necrotizing enterocolitis. Sur Gynaecol Obstet 1993;176:368-70.

11 Saugstad O-D. Neonatal oxygen radical disease. In: David TJ, ed. Recent Advances in Paediatrics, 10. Edinburgh Churchill Livingstone, 1992 :

12 Sullivan JL. Iron, plasma antioxidants and the "oxygen radical disease of prematurity". Am $\mathcal{F}$ Dis Child 1988; 142:1341-4.

13 Shannon KM, MentzerWC, Abels RI. Recombinant human erythropoietin stimulates erythropoiesis and reduces erythropoietin stimulates erythropoiesis and reduces erythrocyte transfusions in very

14 Nex E, Christensen NC, Olesen J. Volume of blood removed for analytical purposes during hospitalization of lowbirthweight infants. Clin Chem 1981;27:759-61.

15 Bifano EM, Miggiani WP, Parker PR. Impact of transfusio practices in premature infants. Pediatr Res 1994;35:216A

16 Emmerson AJB, Coles HJ, Stern CMM, Pearson TC. Double-blind trial of recombinant human erythropoietin in preterm infants. Arch Dis Child 1993;68:291-6.

17 Meyer MP, Meyer JH, Commerford A, Han FM, Sive AA Moller $\mathrm{G}$, et al. Recombinant human erythropoietin in the reatment of the anaemia of prematurity: results of double-blind, placebo-controlled study. Pediatr 1994; 93:918-23.

18 Ohls RK, Christensen RD. Erythropoietin administration to preterm infants during their first two weeks of life: preterm infants during their first two weeks of life: a 33:285A.

19 Ohls RK, Hunter DD, Christensen RD. A randomised, double-blind, placebo-controlled trial of recombinan erythropoietin in treatment of the anaemia of bronchopulmonary dysplasia. I Pediatr 1993;123:996-1000.

20 Shannon KM, Mentzer MC, Abels RI, Freeman P, Newton $\mathrm{N}$, Thompson $\mathrm{D}$, et al. Recombinant human erythropoietin in the anaemia of prematurity: results of a placebo controlled pilot study. $千$ Pediatr 1991;118:949-55.

21 Shannon KM, Mentzer MC, Abels R1, Wertz M, ThayerMoriyama J, $\mathrm{LiWY}$, et al. Enhancement of erythropoiesis Moriyama J, Li WY, et al. Enhancement of erythropoiesis by recombinant human erythropoietin in low birt

22 Bechensteen AG, Haga P, Halvorsen S, Whitelaw A, Liesto $K$, Lindemann $R$, et al. Erythropoietin, protein, and iron supplementation and the prevention of anaemia of prematurity. Arch Dis Child 1993;60:19-23.

23 Ishikawa $A$, International Registry of Perinatal Trials. Record 6925.

24 Maier RF, Obladen M, Scigalla $P$, Linderkamp O, Duc G Hieronimi G, et al. The effect of epoetin beta (recombinant human erythropoietin) on the need for transfusion in very low

25 Obladen M, Scigalla P, Maier RF. Efficacy and safety of recombinat human erythropoietin to prevent anaemias of prematurity. Contrib Nephrol 1991; 88:314-26.

26 Soubasi V, Kremenopoulos G, Diamandi E, Tsantali C, Tsakiris $\mathrm{D}$. In which neonates does early recombinant human erythropoietin treatment prevent anaemia of Prediatr Res 1993; 34: 675-9.

27 Berger J. International Registry of Perinatal Trials. Record 5866.

28 Liu Ea, Mannino FL, Lane TA. Prospective, randomized trial of the safety and efficacy of a limited dsonor exposure transfusion program for premature neonates. $\mathcal{F}$ Pedia 1994; 125: 92-6. 